\title{
EFEKTIVITAS PEMBERDAYAAN MASYARAKAT KURANG MAMPU MELALUI KELOMPOK USAHA BERSAMA (KUBe) DESA LANGKO, KECAMATAN LINGSAR KABUPATEN LOMBOK BARAT
}

\author{
Baiq Sofianti Annisa1, Agustina Ariyani2 \\ ${ }_{1}$ Fakultas Kedokteran Universitas Mataram \\ 2Fakultas Peternakan Universitas Mataram \\ ${ }^{*}$ Co-Author : baiqsofiantia@gmail.com
}

\begin{abstract}
ABSTRAK. Desa Langko merupakan salah satu desa yang berada di kecamatan Lingsar, Kabupaten Lombok Barat, Provinsi Nusa Tenggara Barat. Desa Langko memilki banyak potensi yang dapat dikembangkan dari berbagai sektor, yaitu sektor pertanian, perkebunan, peternakan, kerajianan. dan pengolahan pangan. Oleh karena itu diperlukan adanya pemanfaatan potensi melalui pembentukan kelompok usaha bersama (KUBe) dengan melakukan beberapa tahap kegiatan diantaranya, melakukan identifikasi calon anggota kube, pembentukan kelompok usaha, sosialisasi dengan mengundang pihak dinas sosial serta masyarakat desa, dan pendampingan dalam hal pembentukan struktur kelompok dan pembuatan proposal. Hasil kegiatan yang dilakukan berupa terbentuknya $5 \mathrm{KUBe}$ yang telah siap mengajukan proposal ke pihak dinas sosial yang nantinya akan ditindak lanjuti oleh pemerintah pusat. Dengan demikian kegiatan yang dilakukan tersebut diharapkan dapat menjangkau dan meningkatkan kesejahteraan masyarakat.
\end{abstract}

Kata Kunci: Desa Langko, KUBe, kesejahteraan masyarakat

\begin{abstract}
Langko Village is one of the villages in Lingsar sub-district, West Lombok Regency, West Nusa Tenggara Province. Langko village has a lot of potential that can be developed from various sectors, namely agriculture, plantations, livestock, and hospitality sectors. and food processing. Therefore, it is necessary to utilize the potential through the formation of joint business groups (KUBe) by carrying out several stages of activities including identifying potential prospective members of the cube, forming business groups, socializing by inviting social services and village communities, and assisting in the formation of group structures and proposal making. The results of the activities carried out in the form of the formation of $5 \mathrm{KUBe}$ who are ready to submit proposals to the social service, which will be followed up by the central government. Thus the activities carried out are expected to be able to reach and improve community welfare.
\end{abstract}

Keyword: Langko Village, KUBe, community welfare

\section{PENDAHULUAN}

Desa Langko merupakan salah satu desa yang berada di kecamatan Lingsar, Kabupaten Lombok Barat, Provinsi Nusa Tenggara Barat. Desa ini memiliki jumlah penduduk 6,437 jiwa yang sebagian besar bersuku sasak. Desa Langko merupakan pemekaran dari Desa Duman, disahkan oleh pemerintah tahun 1999. Desa Langko memiliki 7 dusun. Desa Langko memiliki luas wilayah seluas 361,72 Ha. Dengan batas wilayah sebelah utara Desa Giri Madya/Hutan Tutupan. Sebelah 
Timur Desa Karang Bayan, sebelah Selatan Desa Sigerongan, dan sebelah barat Desa Duman, Kecamatan Lingsar.

Munculnya gagasan tentang pemberdayaan masyarakat miskin melalui pendekatan $\mathrm{KUBe}$ didasarkan pada suatu pemikiran bahwa setiap orang memiliki potensi dan kemampuan yang dapat dikembangkan. Potensi ini sifatnya sangat beragam, ada potensi yang dapat berkembang secara individual tanpa bantuan atau campur tangan orang lain dan ada juga potensi yang berkembang dengan bantuan atau pertolongan orang lain atau melalui pendekatan kelompok. Kadang-kadang seseorang atau sekolompok orang kurang menyadari adanya potensi yang dimiliki yang bila dikembangkan bisa melebihi kemampuan dari orang biasa (Puji. 2012).

Secara umum tujuan dari program KUBe adalah mengentaskan kemiskinaan dan mewujudkan kemandirian masyarakat baik secara ekonomi maupun sosial. Sasaran dari program $\mathrm{KUBe}$ adalah masyarakat yang memiliki berbagai keterbatasan penghasilan, pendidikan, perumahan, keterampilan, hubungan sosial, serta mempunyai keinginan untuk berkembang dan mandiri (Abad, 2005). Diharapkan juga upaya ini dapat berkelanjutan dan sebagai upaya untuk memperbaiki kualitas hidup masyarakat dari segi kelompok usaha bersama. Penerapan program $\mathrm{KUBe}$ ini diharapkan mampu meningkatkan pengetahuan masyarakat yang akan mendorong mereka untuk berpartisipasi dalam pemahaman masyarakat terkait pentingnya kerjasama dalam kelompok untuk mendukung kegiatan usaha bersama (KUBe).

\section{ANALISIS PERMASALAHAN}

Desa Langko memilki banyak potensi yang dapat dikembangkan dari berbagai sektor, yaitu sektor pertanian, perkebunan, peternakan, kerajianan. dan pengolahan pangan. Berdasarkan survei pertama ke lapangan, ditemukan bahwa sebagian kecil di setiap dusun sudah ada yang memiliki usaha, namun belum memiliki kelompok usaha bersama atau masih individual. Oleh karena itu diperlukan adanya pembentukan kelompok usaha bersama dengan melakukan beberapa tahap diantaranya yaitu, melakukan identifikasi calon anggota kube, pembentukan kelompok, sosialisasi dengan mengundang pihak dinas sosial, dan pendampingan pembuatan proposal yang nantinya akan diajukan ke dinas sosial. Dengan demikian diharapkan akan dapat menjangkau dan meningkatkan kesejahteraan masyarakat. Dimana anggota KUBe yang masih kurang dalam kemampuan baik dalam segi pendidikan, keterampilan dan pengalaman.,sehingga dapat mendukung keberhasilan KUBe.

\section{SOLUSI YANG DITAWARKAN}

Pelaksanaan kegiatan ini dilakukan secara berkelanjutan melalui kegiatan:

1. Observasi,

2. wawancara serta kegiatan lapangan yang berfokus pada identifikasi,

3. pembentukan kelompok, dan pendampingan,

4. pembuatan proposal terkait kelompok usaha bersama.

\section{HASIL DAN PEMBAHASAN}

Secara garis besar alur pembuatan kelompok usaha bersama adalah: (1) Mahasiswa melakukan identifikasi calon anggota KUBe melalui data dan aplikasi yang berasal dari operator desa; (2) Mahasiswa meminta data terkait persyaratan yang telah dikeluarkan oleh dinas sosial, data yang dikumpulkan seperti KTP, Kartu keluarga, dan Kartu identitas kemiskinan; (3) Mahasiswa memverifikasi data yang telah terkumpul. Kemudian mahasiswa bekerjasama dengan pihak desa membentuk kelompok dengan setiap kelompok beranggotakan 10 orang; (4) Mahasiswa bersama anggota kelompok yang telah terbentuk menentukan struktur orgasisasi dalam kelompok; (6) 
Mahasiswa melakukan sosialisasi kepada kelompok yang telah terbentuk terkait dengan Kelompok Usaha Besama (KUBe) dengan mendatangkan langsung pihak dari dinas sosial; (7) Mahasiswa memberikan pendampingan pembuatan proposal kepada setiap kelompok yang kemudian proposal tersebut akan diajukan ke dinas sosial.

Proses pembentukan kelompok usaha bersama dilakukan melalui beberapa cara sebagai berikut : (1) Diskusi dengan Kepala Desa terkait dengan program kerja; (2) Identifikasi KUBe dengan mengunjungi rumah Kepala Dusun; (3) Pengenalan ke masyarakat terkait program kerja utama KKN tematik KUBe; (4) Verifikasi data persiapan kelompok KUBe; (5) Sosialisasi; dan (6) Pedampingan pembuatan proposal.

Tahap pertama yaitu dilakukan Diskusi dengan Kepala Desa terkait dengan program kerja. Dalam diskusi tersebut mahasiswa memaparkan terkait dengan tema kelompok KKN Tematik Unram. Kegiatan duduk bersama ini menjadi wadah bagi mahasiswa untuk membangun koordinasi dengan perangkat desa.

Langkah kedua, dilakukan identifikasi KUBe dengan mengunjungi rumah Kepala Dusun. Identifikasi kelompok usaha bersama di lakukan dengan mengunjungi setiap rumah kepala dusun yang ada di Desa Langko. Setiap pertemuan mahasiswa menjelaskan terkait tujuan kedatangan mahasiswa mengenai pembentukan kelompok usaha bersama, dengan menjelaskan secara singkat terkait apa itu KUBe, serta persyaratan terkait dengan pembuatan proposal.

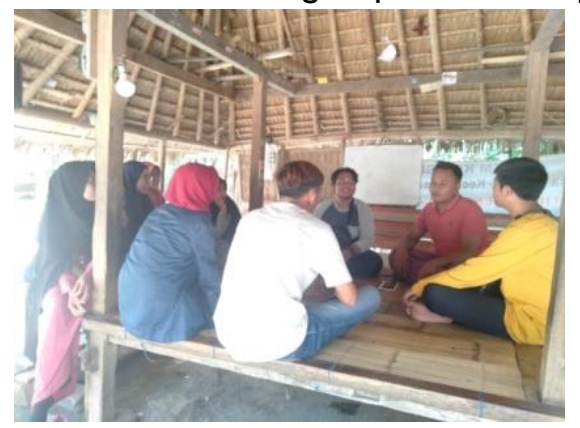

Gambar 1. Kunjungan ke dusun Muhajirin

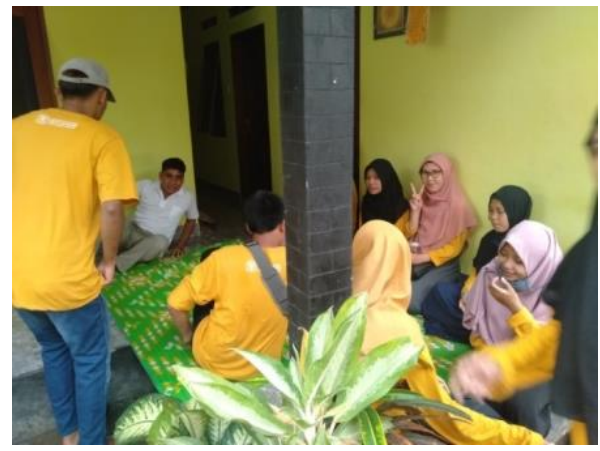

Gambar 2. Proses kunjungan ke dusun Sangiang 


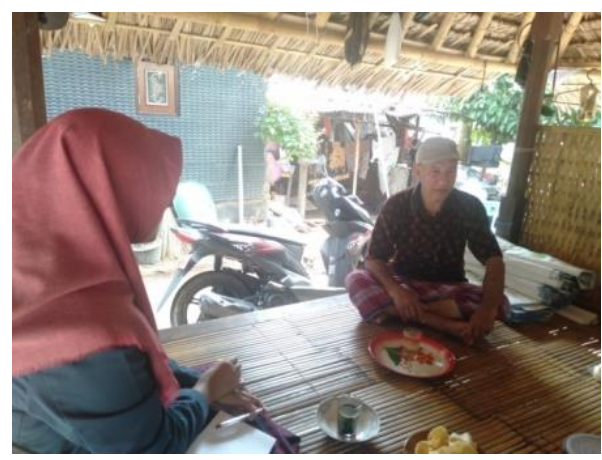

Gambar 3. Proses kunjungan ke dusun Longserang Barat Utara

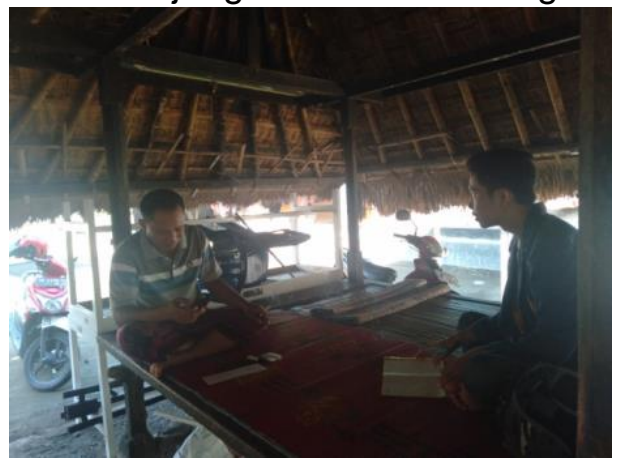

Gambar 4. Proses kunjungan ke dusun Longserang Barat Selatan

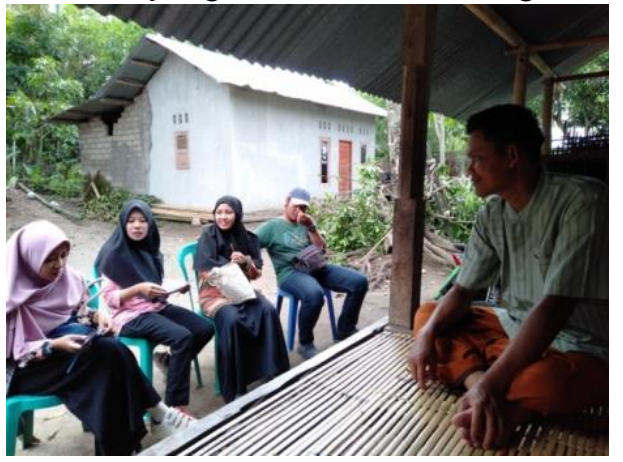

Gambar 5. Proses kunjungan ke dusun Langko Daye

Langkah ketiga, dilakukan pengenalan ke masyarakat terkait program kerja utama KKN tematik KUBe. Proses selanjutnya adalah pengenalan ke masyarakat terkait program kerja utama $\mathrm{KKN}$ tematik KUBe dalam rangka memberikan informasi dan pengenalan singkat terkait program kerja utama.

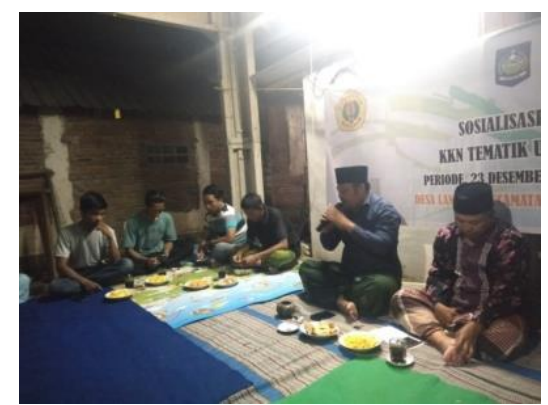

Gambar 6. Pengenalan ke masyarakat terkait program kerja utama KKN tematik KUBe 
Langkah keempat, dilakukan verifikasi data persiapan kelompok KUBe. Data yang telah terkumpul selanjutnya di verifikasi dengan memilah data-data yang sesuai dengan persyaratan yang telah di tentukan oleh dinas sosial. Selanjutnya data yang telah di verifikasi di kelompok kan menjadi satu kelompok dengan beranggotakan 10 orang.

Langkah kelima, tim pengabdian melaksanakan sosialisasi. Kegiatan sosialisasi dilakukan setelah pembentukan kelompok, kelompok yang telah terbentuk di pertemukan dengan pihak dinas sosial yang akan memberikan informasi terkait dengan KUBe.

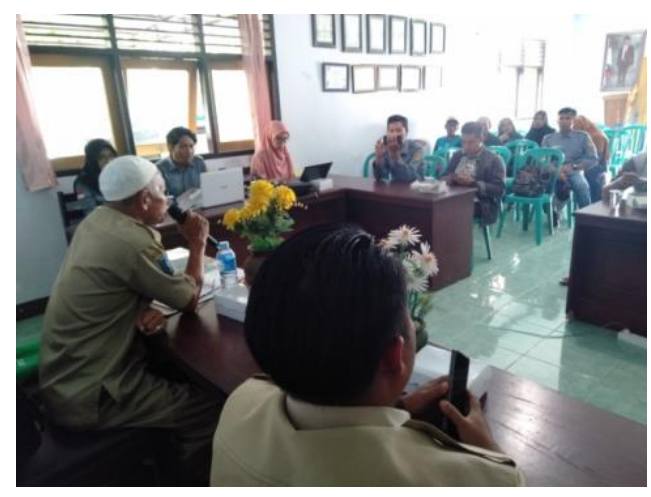

Gambar 7. Kegiatan sosialisasi dengan anggota kelompok usaha bersama

Langkah keenam, dilaksanakan pedampingan pembuatan proposal. Pendampingan pembuatan proposal dilakukan oleh mahasiswa dan anggota kelompok. Pendampingan ini bertujuan untuk memberikan pemahaman serta menambah wawasan anggota kelompok.

\section{KESIMPULAN}

Berdasarkan hasil kegiatan program kerja KKN yang telah dilakukan, diperoleh kesimpulan yakni Peran Kelompok Usaha Bersama (KUBe) dalam menangani kemiskinan meliputi :

1. Kemampuan Intelektual yakni dengan saling bertukar informasi dan ilmu, serta mengerti tugas yang harus dikerjakan.

2. Kemampuan mengatasi sosial psikologi dengan pemberian motivasi, saling percaya antar anggota dan pengelola, menjaga hubungan baik, dan menjalani kemitraan.

3. Meningkatkan keterampilan, dengan adanya pelatihan, saling menyemangati, mengembangkan kemampuan yang dimiliki, serta menyesuaikan kemampuan dengan yang dikerjakan.

4. Meningkatkan taraf kesejahteraan anggota, meningkatkan kemampuan memenuhi kebutuhan dasar, interaksi sosial terjalin dengan baik, meningkatkan kemampuan menghadapi masalah, mengingkatkan pendapatan, serta adanya kerjasama dalam mengembangkan jenis usaha.

\section{REFERENSI}

Abad Badruzaman, Kiri Islam Hasan Hanafi Menggugat Kemapanan Agama dan Politik, Yogyakarta: Tiara Wacana Yogya, 2005

Afrizal, Mohamad. (2014). Pemberdayaan Masyarakat melalui Wirausaha Kerajinan Panel Bambu di Koperasi Kasongan Usaha Bersama (KUB)Kalipucang, Bangunjiwo, Kasihan, Bantul. Universitas Negeri Yogyakarta.

Andi, dkk. (2016). Bahan Ajar Diklat Pendamping KUBE Perdesaan Program Penanganan Fakir Miskin Perdesaan. Jakarta: Kementerian Sosial RI. 
Bagong Suyanto, "Kemiskinan dan Pemberdayaan Masyarakat Miskin,", dalam Jurnal Masyarakat dan Kebudayaan Politik, Jakarta: 2001.

Departemen Sosial RI. (2005). Rencana Strategis Penanggulangan Kemiskinan PROGRAM PEMBERDAYAAN FAKIR MISKIN Tahun 2006-2010. Jakarta.

Haryati Roebyantho, dkk. (2011). Dampak Sosial Ekonomi Program Penanganan Kemiskinan melalui KUBE. Jakarta: P3KS

Republik Indonesia. (2010). PEDOMAN Kelompok Usaha Bersama. Jakarta: Kementerian Sosial RI.

Saifuddin Azwar, Metode Penelitian, Yogyakarta: Pustaka Pelajar, 2010.

Siti Kurnia Widiastuti dkk, Pemberdayaan Masyarakat Marginal, Yogyakarta: Pustaka Pelajar dan LABSA, 2015. 